\title{
Four plus one dimensions of transferability: defining a framework for the application of a landscape characterization in the USA
}

\author{
Stefania Staniscia ${ }^{1 *} \mathbb{D}$, Charles Yuill ${ }^{2}$ and Vincenzo Cribari $^{3}$
}

\begin{abstract}
This perspective article presents considerations based on an attempt for initiating a landscape characterization in the United States using the Landscape Character Assessment (LCA) method initially developed in Great Britain. Literature on LCA underlines the issue of its transferability and the necessity to address, both theoretically and practically, its adaptation when the method is transplanted to other territories. The authors focus on the development of a theoretical framework for the adaptation of the method to a different cultural, geographical, social, political, and institutional context from the one it was designed for. The region of application are West Virginia southern coalfields where mountaintop removal coal mining coexists with rural landscapes, forested mountains, and scarcely inhabited valleys. The significance of conducting a landscape characterization in such an area is acknowledged as well as the necessity to address five dimensions of the question of transferability: physical, cultural, disciplinary, political, and social. In the article the authors examine the British and USA character-based approaches to landscape highlighting the main differences. The environmental history of West Virginia southern coalfields is introduced, and the current landscape is described. Finally, the authors discuss how the five dimensions of transferability can be addressed in the USA context stimulating further theoretical developments and practical attempts of landscape characterization.
\end{abstract}

Keywords: Landscape Character Assessment, Mountaintop removal, Southern coalfields, West Virginia, Appalachian Mountains

\section{Introduction}

This perspective article presents considerations based on an attempt for initiating a landscape characterization in the United States using the Landscape Character Assessment (LCA) method initially developed in Great Britain (Swanwick and Land Use Consultants 2002; Tudor 2014). Literature on LCA underlines the issue of its transferability and the necessity to address, both theoretically and practically, its adaptation when the method is transplanted to other territories (Fairclough et al. 2018b). The

\footnotetext{
*Correspondence: stefania.staniscia@mail.wvu.edu

${ }^{1}$ School of Design and Community Development, Davis College

of Agriculture, Natural Resources and Design, West Virginia University, 4316 Agricultural Sciences Building, 1194 Evansdale Drive, Morgantown, WV 26506-6108, USA

Full list of author information is available at the end of the article
}

authors, thus, focus on the development of a theoretical framework for the adaptation of the method to a different cultural, geographical, social, political, and institutional context from the one it was designed for. The region of application are West Virginia (WV) southern coalfields, an area where mountaintop removal (MTR) coal mining coexists with rural landscapes, forested mountains, and narrow scarcely inhabited rugged valleys.

The utility of landscape characterization in the United States of America (USA) is due to the need for a character-based or descriptive approach to landscape which can be applied to both everyday and outstanding landscapes, which does not exclusively focus on landscape aesthetics and scenic values, and doesn't solely apply to federal and/ or federally managed lands. Indeed, USA approaches to landscape characterization focus mainly on natural scenery and visual resources (Palmer and Smardon 2018) and 
are thus inadequate for studying everyday and degraded landscapes such as the one under consideration. In fact, although very characteristic, the Appalachian landscape of WV southern coalfields is heavily altered because of the presence of the mining activity and specifically of MTR (Fig. 1). Moreover, the areas majorly impacted by MTR often are not even visible from beaten tracks and inhabited places because they can be found in high elevations, on top of ridges while major infrastructural corridors and settlements lay on valley floors. It is, thus, impractical to develop a characterization for this region that relies on viewpoints, viewsheds, and views.

In the following section the authors examine the British and USA character-based approaches to landscape highlighting the main differences in terms of purpose and scope. In order to explicitly delimit the field of interest of these reflections, it is worth clarifying that, with reference to the USA context, for the sake of comparability, the authors only considered the approaches that address the landscape as a combination of ecological, perceptual, aesthetic, cultural, and social components and which aim to merely build 'situation analysis' (Stahlschmidt et al. 2017, p. 16) not necessarily action-oriented. By way of example, they dismiss the McHargian legacy of the

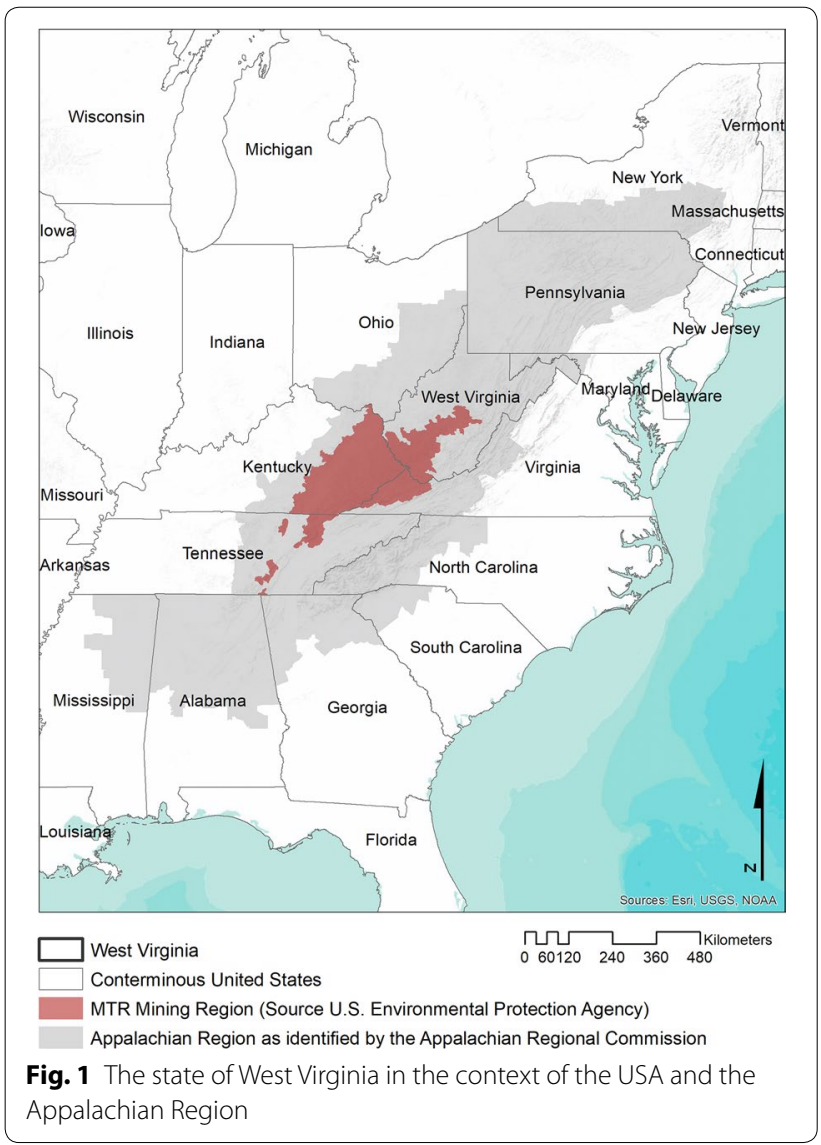

ecological planning method which is based on the idea of the primacy of the ecological factors. This section is meant to explain the main reasons behind the attempt to utilize the British-based method in a USA context. In the third section, the description of the region of application follows. The authors introduce the environmental history of WV southern coalfields describing the changes which had contributed to define the main historical processes that produced the current landscape. Particular attention is paid to the description of coal mining related activities and events that heavily shaped the physical, cultural, and social landscapes of the region. The significance of a landscape characterization of the area is depicted in the fourth part of the article. The theoretical framework for the LCA method adaptation to the USA and WV conditions is then summarized after Fairclough et al. (2018b) four dimensions of the transferability question: physical, cultural, disciplinary, and political. A fifth dimension is then introduced by the authors and explained. Final remarks conclude the article.

\section{Methods}

\section{Landscape characterization. A comparison between the British and USA approaches The LCA method}

The LCA method has been widely described and discussed from several perspectives (Fairclough et al. 2018a; Butler 2016; Sarlöv Herlin 2016; Olwig 2016; Brabyn 2009; Ode et al. 2008; among others) and case studies of its application are well documented in the literature. Also, a recently published book by Fairclough et al. (2018a) offers an extensive and up to date international overview of character-based landscape approaches in Europe, the USA, and in the wider world through which a comparison of different available methods is possible. Therefore, this overview merely aims at underlining the origin and main purposes of the approach, alongside a short description of its application process and the main issues with its transferability to different physical, cultural and political/institutional contexts.

Current landscape character-based approaches originated in the United Kingdom (UK) in the mid-80 s due to the need to protect the landscape and the countryside from risks resulting from 'early industrialization and urbanisation (...) [and] high population density and hence hard pressure on the rural landscape' (Sarlöv Herlin 2016, p. 182). While earlier approaches emphasized an evaluative attitude toward the landscape-distinguishing good and beautiful landscapes from bad and ugly ones-after the mid-90 s the focus shifted to the notion of landscape character and its identification, where character is defined as '[a] distinct, recognizable and consistent pattern of elements in the landscape that makes one 
landscape different from another, rather than better or worse' (Swanwick and Consultants 2002, p. 8).

LCA is a method 'designed to enable strategic landscape decisions in spatial planning and development control, archaeological management and landscape management or stewardship' (Swanwick and Fairclough 2018, p. 26). It is what is defined as a 'situation analysis', which is 'aimed at gaining knowledge and understanding of a landscape in advance of any specific proposals, and [is] not linked to specific plans or actions' (Stahlschmidt et al. 2017, p. 16). This makes it an important practical tool for supporting decision- and policy-makers as well as landscape managers.

LCA is applied, at different scales, to the entire territory of the UK, a formalized and structured approach that identifies the character of a landscape (i.e. what makes it distinctive) and, when assessing the impacts of prospective transformations, enables a judgment regarding the qualities and values embedded in the landscape. The identification phase is based on the inventory and description of every component of the landscape, both natural and cultural, and the way they interact and combine to create a distinguished character. This effort comprises both desk and field work. The first is a 'bird's eye view of the landscape based primarily on maps and aerial photographs. (...) Field work provides the ground level view, allowing identification of components of the landscape and the aesthetic and perceptual characteristics that cannot be identified from desk work' (Swanwick and Fairclough 2018, p. 24).

Public consultation and the involvement of both stakeholders and laypeople is part of several steps of the process, but LCA is primarily an expert-led procedure based on professional judgement. This is considered by several scholars to be one of the main shortcomings of the method (Warnock and Griffiths 2015; Butler 2016; Fairclough and Herring 2016; Swanwick and Fairclough 2018). In fact, in a time in which it is assumed that landscape is everywhere, that it is related to people's perception and that it plays an important public interest role contributing, for example, to human well-being (Council of Europe 2000) more emphasis is expected to be placed on the effort to democratize landscape identification, assessment, management, and planning increasing the level of public participation and engagement.

When the European Landscape Convention (ELC) of the Council of Europe came into force in 2000, the role of LCA was strengthened, resulting in the widespread adoption of the method by other European countries (Fairclough et al. 2018b; Swanwick and Fairclough 2018; Sarlöv Herlin 2016). The ELC acknowledges the role that the landscape plays in people's quality of life, and that this is true for all landscapes, whether everyday, degraded, or outstanding. This entails rights and responsibilities for everyone to protect, manage, and plan the landscape. Furthermore, this requires states to implement the Convention and, among other measures, engage in landscape identification and assessment (Council of Europe 2000). Due to the availability of LCA guidelines online, the fact that it is accessible in English, and the straightforwardness of the methodology, LCA became the most influential method in Europe for landscape identification and assessment (Fairclough et al. 2018b; Swanwick and Fairclough 2018; Sarlöv Herlin 2016). For the same reasons, this method has been also applied in extra-European countries (Fairclough et al. 2018a; Sarlöv Herlin 2016; Li and Zhang 2017; Bartlett et al. 2017).

However, the adoption of the method in a different context from the one it was designed for doesn't come without challenges as highlighted by Fairclough et al. (2018b) referring to both the Landscape Character Assessment and the Historic Landscape Characterisation (HLC). In fact, the significance of the influence of the historical, physical, cultural, and linguistic context on the origin and development of LCA and HLC has been widely acknowledged along with the need to adapt the method when exporting it to other countries (Sarlöv Herlin 2016; Fairclough et al. 2018b).

Fairclough et al., writing about the 'question of transferability' of the British-based methods, name 'at least four dimensions' (2018b, p. 12). The first one refers to the challenge posed by the diversity of the physical context of application. The English landscape has 'a strong degree of legibility through its physical components' (Fairclough et al. 2018b, p. 12). The visual, physical, and administrative borders nearly completely match because of the strong correspondence between visual lines, ownership, and landscape types (Sarlöv Herlin 2016). However, this isn't true for every landscape. The second dimension concerns the cultural context which the method is expression of referring to the potentially different acceptations of the word landscape and the implications it can have on the aim and scope of landscape characterization implementation. The third dimension pertains to the disciplinary context from which the methods arose, that is landscape and environmental planning and archaeology, whose methodologies influenced the development of the British-based methods. Finally, the fourth dimension refers to the political and institutional environment within which the method is implemented and that, in the British context, 'provided a sound platform for LCA to be applied in practice, moving onwards from the old essentially defensive approaches of selective designation?' (Fairclough et al. 2018b, p. 13).

The spatial and temporal concurrence of the factors that made the British-based methods and their 
implementation possible doesn't always happen and therefore very often it takes a certain degree of adaptation when the methods are applied in a different context.

\section{The USA approach}

Main considerations in this section draw upon 30 years of research as summarized in the book chapter authored by Palmer and Smardon included in the handbook of Landscape Character Assessment (2018). In the chapter, the authors describe the state of the art in character-based approaches in the USA, mostly focusing on the federal level 'in the absence of a single approach to landscape character at the national or state levels' and concentrating on 'the three situations within which landscape character assessment methods are most employed in the USA: landscape planning, federal land management and visual impact assessment' (Palmer and Smardon 2018, p. 131). Several aspects of these considerations are relevant to our reflections and will thus be discussed in what follows with the intent to highlight the characteristics which make the current mainstream USA approach unsuitable for properly addressing landscape characterization of everyday landscapes, thus resulting hardly applicable to the area under consideration.

One aspect of the USA approach which is worth noting is the considerable attention paid to landscape aesthetics and scenic values. '[W] hereas in many European countries (...) there has been a move toward a more inclusive concept of landscape and away from a scenic emphasis, in America the emphasis on conserving scenery continues to be broadly influential' (Palmer and Smardon 2018, p. 132). The relevance of the visual aspects of natural scenery influences the way sites worthy of protection are designated and managed. One of the main consequences of this approach is the establishment of landscape values principally based on scenic properties. The emphasis on the scenic has notable effects on the notion, policy, and planning of landscapes, as it implies that only specific areas are worthy of protection while, implicitly, the rest of the land is in some way expendable. Therefore, landscape management- and protection-related activities are based on a selective designation and, because of it, confined to very specific areas.

The aforementioned activities are mostly conducted by federal land management agencies: the United States (U.S.) Department of the Interior, Bureau of Land Management and the U.S. Department of Agriculture, Forest Service. Moreover, these activities are mainly concerned with visual impact, often consisting of visual impact assessment action-oriented studies carried out to assess the potential changes introduced to the scenic attributes of a landscape by a prospective project. In fact, the two abovementioned federal agencies have developed their own 'situation analyses' (Stahlschmidt et al. 2017) of the land they plan and manage, both focusing, among other things, on visual resources, landscape aesthetics, and scenery. Although, it should be noticed that the U.S. Department of Agriculture, Forest Service in 2005 introduced the Terrestrial Ecological Unit Inventory (TEUI) for lands administered by the Department. This is a system that is meant to classify ecosystem types and map ecological units. The information and maps resulted from the classification are used in natural resource inventory, monitoring, and evaluation; in land management planning; and in describing land capability and identifying suitability for various uses. The purpose of the TEUI is similar to the one of the LCA but it only applies to National Forest System lands and it focuses on ecological characters rather than on landscape ones. Moreover, it only uses ecosystem components for the characters identification such as geology, climate, soils, hydrology, and vegetation. In conclusion, ' $t$ t]he most common way that landscape character is considered in the USA (...) is through visual impact assessment' (Palmer and Smardon 2018, p. 141).

However, starting at the end of the 1960s several multi-state planning experiences occurred at the level of regional river basins. In fact, the Federal Water Resources Planning Act of 1965 (U.S.) provided for the formation of regional river basin commissions, and funded the states to develop comprehensive water and related land resources plans. Of the plans produced in the wake of the Act, two are worthy of attention because they represented promising approaches to landscape character assessment due to their innovative methods and physical extent (Palmer and Smardon 2018). These were the Upper Mississippi River Comprehensive Basin Study and the North Atlantic Regional Water Resources Study, both aimed at producing environmental planning for major river basins. The studies included appendixes with regional landscape inventories: Appendix B Aesthetic and Cultural Values, prepared by Lewis, Jr. and Associates in 1969, and Appendix N Visual and Cultural Environment, prepared by Research Planning and Design Associates, Inc. in 1970, respectively. It is worth noting that the two documents include in their titles the word 'cultural' in addition to terms which emphasize visual and aesthetic attributes. While these two studies represent the closest approach to the LCA method in the USA, they have not been followed up.

In the 1969 document, the authors stressed the need to identify both natural and cultural features 'progressing from sight to insight' (Lewis and Associates 1969 , p. 93). Although 'change and variety' were the most relevant attributes for landscape appreciationthat is emphasizing the relevance of the visual aspect, 
the authors acknowledged the value of other features, dividing the landscape into intrinsic and extrinsic values, the former being natural resources and the latter being 'man-made changes, adaptions and additions to the natural resources' (Lewis and Associates 1969, p. 23). In fact, in the guidelines for creating the inventory, water features, land forms, vegetation, and wildlife were listed together with cultural resources such as bridges, historical markers, battlefields, sites, and objects pertaining to early Native American culture. Significant similarities between this study and the LCA approach include the search for natural patterns in the watershed landscape, the identification of the corridor pattern as 'the most significant form determinant pattern[s] for providing valuable experiences for living, working, and playing' (Lewis and Associates 1969, p. 143), and the definition of Landscape Personality Pattern as the 'distinguishing characteristic' of a specific area made by the combination of natural formations and human manipulations of the same. Thus, in this study, natural and man-made features were equally considered, and the otherwise prevalent scenic emphasis was underplayed.

In the 1970 study, although the interplay between natural and anthropogenic factors was also acknowledged, the emphasis laid on the visual characteristics of that interplay: the study developed a landscape inventory technique which 'was based upon visual indicators' with the inventory phase involving 'the identification of visual and cultural qualities in the landscape' (Research Planning and Design Associates Inc. 1970, p. N-3). It took into consideration both landform and landscape/ ground patterns, the former being the expression of the natural landscape and the latter the visual manifestation of the anthropogenic effect. This led to the definition of Landscape Series-'divisions of the landscape which are identified by the general visual impression gain from the repetition of a dominant landform over a large area'-and Landscape Units-'consistent ground pattern - the two-dimensional distribution of man-made structures and man-manipulated resources on the landscape' (Research Planning and Design Associates Inc. 1970, p. N-17-18). Series and Units were assessed quantitatively, based on abundance or scarcity, and qualitatively, based on visual contrast and diversity of spatial configuration.

As already mentioned, although these two studies 'have influenced state and local planning efforts' (Palmer and Smardon 2018, p. 133), they have not inspired further applications in the USA and, thus, the approach to landscape characterization is still based on visual and aesthetic considerations and mainly operates on federal land or in relation to federal projects. As such, it is selective in purpose and scope, therefore its application to an everyday, although very characteristic landscape as the one that is the object of this article, is unsuitable.

However, it is worth noting that there has been a more recent experiment for conducting a historic landscape characterization for heritage management at Fort Hood in Texas. The work was inspired by the British-based method (Dingwall and Gaffney 2007). In Fort Hood over 2000 archeological sites coexist with a military reservation which represents a challenge for the stewardship and management of the cultural resources in the area. 'The Fort Hood 'experiment' (...) not only migrates a European philosophy and its techniques into the New World, but expands and refines the method in a variety of useful ways' for example using remote sensing data and advanced Geographic Information Systems (Fairclough 2007, p. ix). However, as far as the authors knowledge goes, this experiment has not been repeated and confirms the traditional USA approach of selective designation which concerns public and protected lands.

\section{Results \\ West Virginia southern coalfields: a selective overview}

The following description introduces the environmental history of WV southern coalfields and the changes which had contributed to defining the main historical processes that produced the current landscape. The authors deemed relevant, for the sake of a better understanding of the following sections of the article, to dedicate particular attention to the description of coal mining related activities and events that heavily shaped the physical, cultural, and social landscapes of this region.

The Appalachian Highlands are one of eight physiographic regions of the United States, and the Appalachian Plateau (AP) is one of its seven divisions based on specific geomorphological characteristics (following Fenneman 1928). Altitudes are lower closer to the Ohio River, with averages of about 365 to $430 \mathrm{~m}$, progressively increasing eastwards where, at the WV border, the highest peak measures around $1220 \mathrm{~m}$ (Thornbury 1965). The $\mathrm{AP}$ is characterized by an abundance of shale formations and a mixed mesophytic forest (Braun 1950), which Hinkle et al. defined as 'among the most (if not the most) biologically rich systems of the temperate regions of the world, certainly in the United States' (1993, p. 203).

This geographic region has been 'strongly shaped by a combination of the physiography and early migration patterns' (Pillsbury 2006, p. 4), which helps to identify the sub-regions it is divided into. WV is in the Upland South, characterized by the presence of the Appalachian Mountains, which represented the first barrier to westward migration. Major physiographic regions include the Allegheny Plateau of the western two-thirds of the state, the Allegheny Mountains, and the Ridge and Valley province 
to the east (Fenneman 1928; Core 1966). According to the U.S. Census Bureau, this is a rural and mountainous region. The area is scarcely populated, and its inhabitants are mainly concentrated in valley bottoms.

WV has a history of extensive natural resources extraction of forest, coal, and, more recently, natural gas. Although WV is a rich region in terms of natural capital resources, human communities in the southern coalfield area remain among the poorest in the state, which is already among the poorest states in the USA, epitomizing 'the paradox of wretched poverty in an area teeming with rich resources' (Loh cited in McGinley 2004, p. 42).

The first relevant landscape change in the region was induced by the arrival of the first settlers from southeastern Pennsylvania, Virginia, and Coastal Piedmont of the Carolinas, who built agrarian settlements and whose economy was based on dispersed, independent subsistence farming. Since the middle of the 18th century, the region underwent other big changes, the main ones starting with the industrialization of the Appalachian South from 1880 to 1930 . The advent of the lumber industry extensively exploited the mixed mesophytic forest, converting once lush forested mountains into threadbare lands. At the same time, the coal industry started up and, after less than a half of a century of underground mining, in the mid 1910s it began the practice of surface mining which progressed to MTR in the early 1970s.

Coal mining in WV is now decreasing in significance due to several factors, including the depletion of the richest coalfields of the south and the boom of cheaper and less labor-intensive exploitation of oil and natural gas. Nevertheless, the effects of surface mining and in particular of MTR on the landscape, the environment, and the communities are continuing, long lasting, and potentially devastating.

\section{A focus on vegetation}

Earl Core, in his 1966 seminal book about the vegetation of WV, recognized that the existing vegetation of West Virginia has been greatly affected by human activity, chiefly since the middle of the 18th century' (p. 32). The primeval forest-according to Core's definition, the mountain forest (including northern evergreen forest and northern hardwood forest) and mixed hardwood forest-began to disappear with the arrival of white settlers. At the time of his writing, the Cathedral State Park in Preston County, an 'area of 118 acres[,] may be the only sizable stand of virgin timber in the State' (Core 1966, p. 113).

Core lists several causes of ' $t \mathrm{t}] \mathrm{he}$ change from natural to "cultural vegetation"' (1966, p. 113). First, settlers needed to clear the land for agriculture. Small quantities of the cut wood were used, and the excess was burned.
Several surroundings areas were accidentally damaged by uncontrolled fires. Road construction also contributed to the destruction of the forest. Furthermore, Core lists the use of charcoal in the rising manufacturing industries and finally the construction of the railroads that required large quantities of wood as significant contributors to the loss of forest. Finally, strip mining for coal also contributed to the deforestation. 'By 1950 approximately 70,000 acres had been affected and about 2000 acres were being added annually' (Core 1966, p. 122). Deforestation was at its peak in the 40 years from 1880 to 1920 , when WV went from being two-thirds covered by ancient growth hardwood forest to being virtually completely deforested (Lewis 1998).

Commercial logging wood-cutting intensity increased as the technology progressed; sawmills evolved from basic to more advanced. Logging also increased with the coming of the railroads (Eller 1982). At the beginning of the 20th century, railroads extended to almost every portion of WV, penetrating 51 of the 55 counties (Garvin 1907). After the mountains were deforested, lumber companies closed their operations and left the region, leaving behind an impoverished environment (Lewis 1998). Coal mining followed a similar pattern.

\section{Coal mining}

The first reference to coal in WV dates to 1742, when John Peter Salley reported the presence of coal along what was later named the Coal River. The first area in which numerous mines opened was the Kanawha Valley around 1817. Those mines stayed open until the outbreak of the Civil War (1861-1865), after which a renewed interest in mineral resource exploitation led to the development of mining operations in new localities (Eggleston 1975). By 1880, numerous coal mines and mining company towns had been established in WV. Industrial cities and coal camps characterized the urban landscape, while traditional farmsteads in small hollows characterized the agrarian one (Pillsbury 2006). The southern coalfields opened after 1870, owing their success to the railway expansion.

With developments in mechanization, mining methods changed and improved. In the beginning, coal was surface mined with picks and shovels, after which deep mining was introduced, and electrification came about by 1890 . Large-scale surface mining started in 1914, and with rapid progress in mechanization large mining machinery came into common use after 1936 (Eggleston 1975). Surface mining took different forms: area and contour mines were the dominant types in WV until larger earthmoving equipment was introduced and the MTR method became viable. In 1970 at Bullpush Mountain in 
WV, the first MTR operation in the USA was established (Burns 2007 cited in Stretesky and Lynch 2011).

\section{Mountaintop removal mining}

MTR is the practice of surface mining coal seams that lie under several feet of rock. The process begins with clearcutting the mountain, blasting the rocks and soil situated above the seam of coal, dumping the overburden (trees, soil, rocks) into the heads of hollows adjacent to the removed mountaintop burying streams, and finally surface mining with draglines the sometimes even a few feet shallow coal seam. Processing coal also requires it to be washed before being transported to the market to separate it from the surrounding soil and rock. The washing process generates huge volumes of liquid waste that is usually impounded with the construction of dams. The regulation requires the surfaced mine to be reclaimed; however, reclamation is often limited to barren grassland (Fig. 2). Landscape is heavily altered by this practice: land is levelled, streams are buried and water flow and quality are adversely impacted, there are greater risks of flood and soil erosion, while deforestation and loss of species diversity occurs as well.

MTR has also detrimental social and economic consequences on coalfield communities. Among several others, there are, for example, coal town disappearance, property damage, cemetery removal or destruction, increased damages from flash floods, 'the enclosure of lands heretofore treated as commons for hunting, gathering, fishing, and other communal use' (Hufford n.d., p. 32) and several physical and mental distresses such as increase in disease and deaths because of contaminated air and water, depression (Hendryx 2018), and solastalgia (Albrecht 2005).

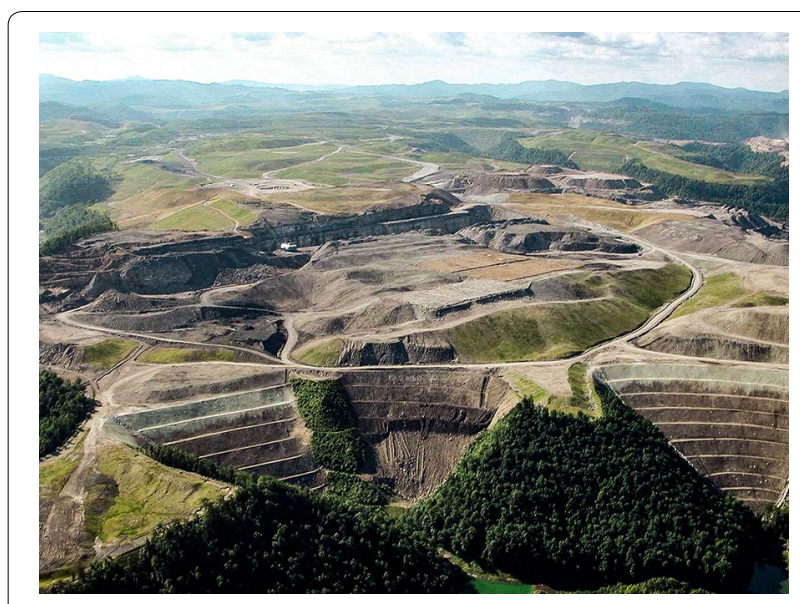

Fig. 2 Kayford mountain, MTR site after reclamation. Photo: Vivian Stockman with the Ohio Valley Environmental Coalition; Flyover courtesy SouthWings
From this brief description emerges the image of a landscape that has been profoundly shaped by anthropogenic activities and that represents the physical evidence of the interaction between humankind and its natural environment. In particular, MTR emerges as 'the dominant form of (...) land cover change in the Central Appalachian ecoregion' (Ross et al. 2016, p. 2064) and a key driver of major landscape changes in WV southern coalfields.

\section{The significance of landscape characterization in an MTR mining area}

Rationale for conducting landscape characterizations

The effort of landscape characters identification-and, only later, of landscape values assessment as 'tool to identify and assess the significance of and the effects of change resulting from development' (Landscape Institute and Institute of Environmental Management \& Assessment 2013, p. 4)-is essentially related to the need to control and manage landscape changes to ensure they do not negatively affect, or do so to a lesser extent, the valued distinctive aspects of landscapes. This is needed today more than ever because landscape changes occur at a rapid pace and technology allows humanity to make radical and often irreversible changes (Council of Europe 2000). It is not by chance that the current era is referred to as the Anthropocene (Crutzen 2002).

Landscape inventory, classification, and analysis are tools created for making wise decisions about the future of the land. The earlier a landscape description is made the more valuable it is since it can be used as a strategic tool to forestall unwelcome changes or to minimize their impact. The task of defining landscape baseline conditions identifying, locating, and mapping landscape elements and attributes is the first basic step toward more conscious landscape design, planning, and management (Fairclough et al. 2018a; Stahlschmidt et al. 2017; among others).

Landscape inventories are also the main and perhaps only means to acknowledge the existence of the landscape and to reify it for policy- and decision-makers and for the community at large. The absence of an assessment of the landscape baseline conditions increases the risk of landscapes obliteration. Features not represented in maps, in fact, are often overlooked in decision-making, planning, and resource management matters with adverse effects on local communities that can experience their cherished landscapes to vanish because of inadvertent or vested interests derived planning (Wartmann and Purves 2017).

Philip Lewis' words express the urgency of dealing with the above-mentioned risk. In the introduction to Appendix B, he writes: '[i]t is easy to talk about environments 
in generalities, but the task of protecting and enhancing the remaining attributes that provide diversity requires, in the first place, the task of identifying, evaluating, and locating the attributes in the real, living landscape. (...) I firmly believe that it is the task of every citizen to be aware of the attributes in his own locality and to demand that they are located and mapped on a county by county basis' (1969). Lewis indirectly also issues a call to action for every citizen to exercise their rights and duties towards the landscape. Landscape is today widely recognized as an important component of quality of life (Council of Europe 2000) and 'as an aspect of the right to quality of life' (Fairclough et al. 2018a, p. 14) as, for example, in the Portuguese Constitution (Council of Europe 2005). Scholars and policy- and decision-makers also agree in the definition of landscape as a human right (Egoz et al. 2011). As such, citizens have the right to enjoy the landscape as well as the duty to protect it. To do so, however, it must be recognized to begin with.

\section{Undertaking the landscape characterization in WV southern coalfields}

Context specific reasons for conducting a landscape characterization of WV southern coalfields reside in the distinctiveness of the area under consideration and the dramatic ongoing landscape changes due to MTR that put the landscape under threat of irreversible changes. In fact, in a report published on Science in Palmer et al. 2010 defined the impacts of MTR as 'pervasive and irreversible'; they also stated that 'mitigation cannot compensate for losses.' (p. 149) Furthermore, while impacts of MTR on health and environment have been thoroughly studied, the terrestrial impacts of MTR have been neglected (Wickham et al. 2013) although they have been largely acknowledged by scholars and lay audience as well. As a matter of fact, to the best of the authors knowledge, no studies have been conducted in the region on landscape characterization or landscape changes due to MTR.

As already mentioned, MTR is a mining practice that is redefining the outline of the mountains in the range of hundreds of meters. Very likely, it is also one of the main manifestations of the Anthropocene (Crutzen 2002). As a matter of fact, the National Aeronautics and Space Administration (NASA) Earth Observatory has covered the phenomenon since 2007 and listed MTR mining in WV in the World of Change section of its website together with the Antarctic Ozone Hole, the Amazon Deforestation and other anthropogenic phenomena that are producing significant changes on earth (NASA Earth Observatory n.d.).

Research conducted by Hooke (1999) compared the spatial distribution of humans and rivers geomorphic activity in the USA, demonstrating that the highest rate of earth moved is in WV and neighbouring states and it is due to coal mining activities. Hooke defined humans as today greatest 'geomorphic agents' (1999, p. 688) whereas rivers are only second. Ross et al. in their research on the effects of MTR on surface topography, bedrock structure and downstream waters, described its effects on landscape comparing them to the ones produced by volcanic eruptions 'where the entire landscape is fractured, deepened, and decoupled from prior landscape evolution trajectories, effectively resetting the clock on landscape and ecosystem coevolution.' (2016, p. 2071). Changes due to MTR are dramatic in scale both size and time wise (Fig. 3).

Although many of MTR major changes have already happened, undertaking a landscape characterization of the region is still useful to build the baseline conditions against which to assess further changes related, for instance, to reclamation processes or further exploitation that are likely to happen in the same area in the near future. In fact, in Southern WV in 2018 there are still more than 500 million tons of recoverable coal. This figure represents the quantity of coal that can be still surface mined from existing coal reserves at producing mines (U.S. Energy Information Administration 2019). The implication is that the risk of MTR mining is still very actual.

However, natural resources extraction and, in particular, coal mine has always been a hotly contested ground. Southern WV has a history of activism, community mobilization, and organized resistance starting in the early 1900s with the so-called mine wars, battles for the legal recognition of labour unions in the mines. Protests also occurred in the 1990s against contour mining and MTR, and in the present-day communities fight

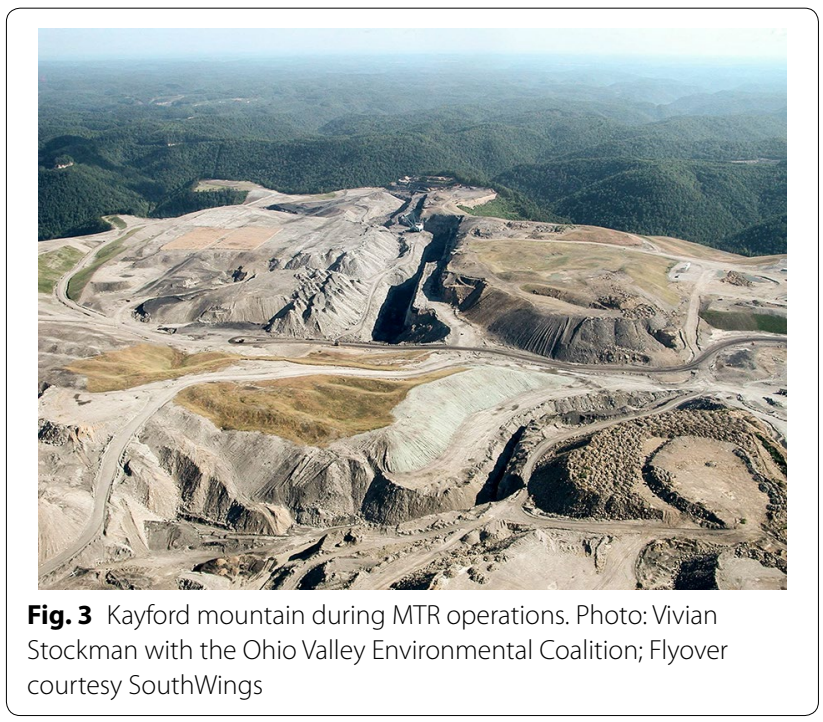


against natural gas extraction through fracking and the construction of major natural gas pipelines. Though, the communities are also divided. Many people think that coal mining, despite its negative effects, brings much needed jobs to the area. However, there is little empirical evidence for the correlation between surface mining and economic development (Woods and Gordon 2011). On the contrary, scholars have demonstrated that coalfield communities are the poorest in the state as well as the ones where environmental violations are most likely to occur (Stretesky and Lynch 2011).

Nowadays, communities in southern WV are calling for a transition of the state toward a more sustainable model of development and for diversified new energy economies. Proposals and projects have been made for the reclamation of former mine sites transforming them into renewable energy facilities. Efforts are underway toward the designation of part of Southern WV coalfields as a Geopark. West Virginia University (2018), partnering with National Coal Heritage and U.S. Geological Survey, is the promoter of an initiative for the creation of an Appalachian Geopark with the goal to protect geological sites of international significance and encourage the sustainable use of geo-sites for knowledge-transfer activities. Although this is currently an aspiring project, reflections have been developed in academic environment for the consideration of MTR mining as industrial heritage emphasizing its relevance as representative testimony of the Anthropocene era (Staniscia and Yuill 2017).

In the situation so far described in which heavy industrial activities clash with community aspirations for a transition towards a more sustainable development model and with the needs to defend the right to landscape quality, landscape characterization can play a critical role in pushing for 'an informed shaping of future landscapes' (Fairclough et al. 2018b, p. 18) and a more sensitive land stewardship.

\section{Discussion}

\section{Addressing the question of transferability}

As noted previously, Fairclough et al. (2018b) write about the question of transferability of the British-based methods pointing out 'at least four dimensions' (p. 12) of it. In the following pages, the authors discuss the Fairclough et al. dimensions relating them to a potential application of the LCA method to the USA context and specifically to WV southern coalfields in the attempt for initiating a landscape characterization process.

\section{The first dimension-differences in the physical attributes}

The first dimension named by Fairclough et al. concerns the diversity of the physical attributes that, in this case, characterize the British and USA landscapes. Both LCA and HLC are tailored to the specificities of the 'English landscape, with its typical elements of cities, towns and villages with characteristic architecture and settlement patterns, fields enclosed with hedgerows or stone walls, rolling green lowlands and hilly heather uplands, ancient woodlands and layer upon layer of historical palimpsests' (Sarlöv Herlin 2016, p. 176).

WV southern coalfields present a very different landscape in terms of scale, grain, and time depth. It is characterized by low diversity in terms of land cover types and their configuration. Reading a land cover map of the region, it is possible to infer that the dominant land cover type is the forest. Bare or grassy plateau-like surfaces due to post-mining reclamation are size-wise the second land cover type (Fig. 4). When reading a topographic map of the area, the landscape can be described as a continuous surface of hills and hollows which raggedness gradually diminishes moving westward from the Allegheny Plateau toward the Ohio River valley (Fig. 5).

Two seems to be the main differences between the British and WV southern coalfield landscapes. The first one is 'the partial absence of physical land divisions such as hedges or walls' (Fairclough 2007, p. vii), the lack of the demarcation lines that define field patterns and that represent an invariant of the British landscape. The second one is the scale of landscape 'that is not characterised by

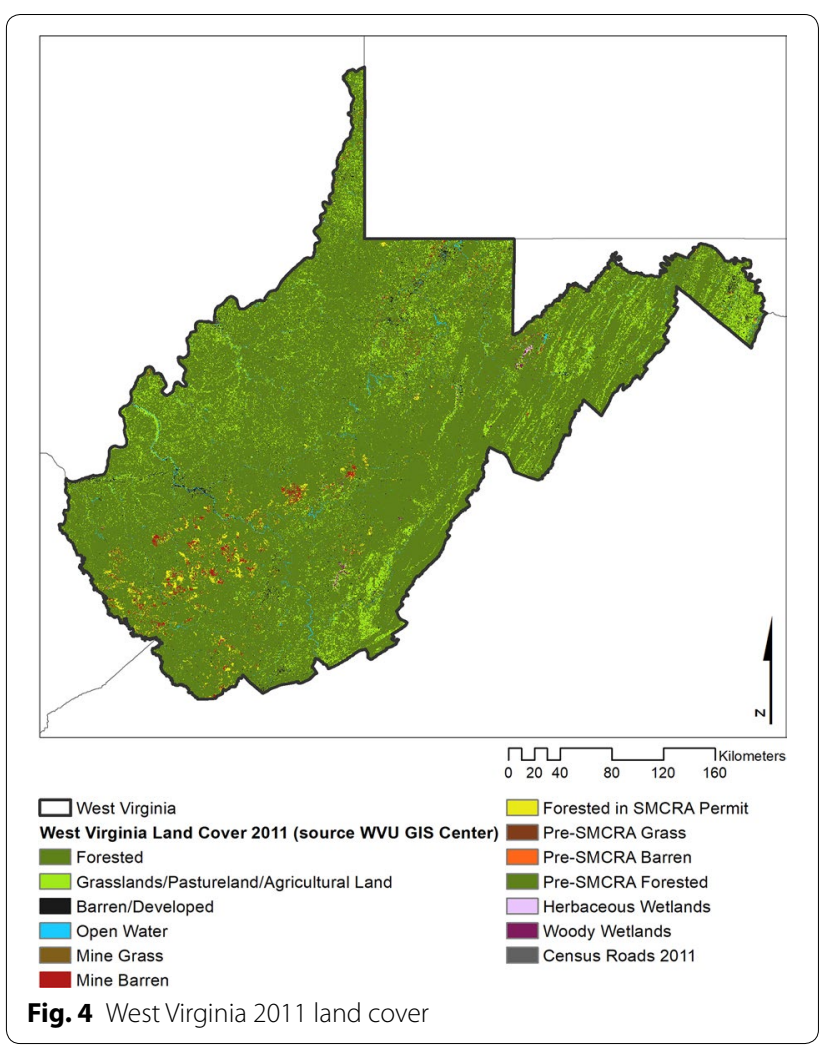




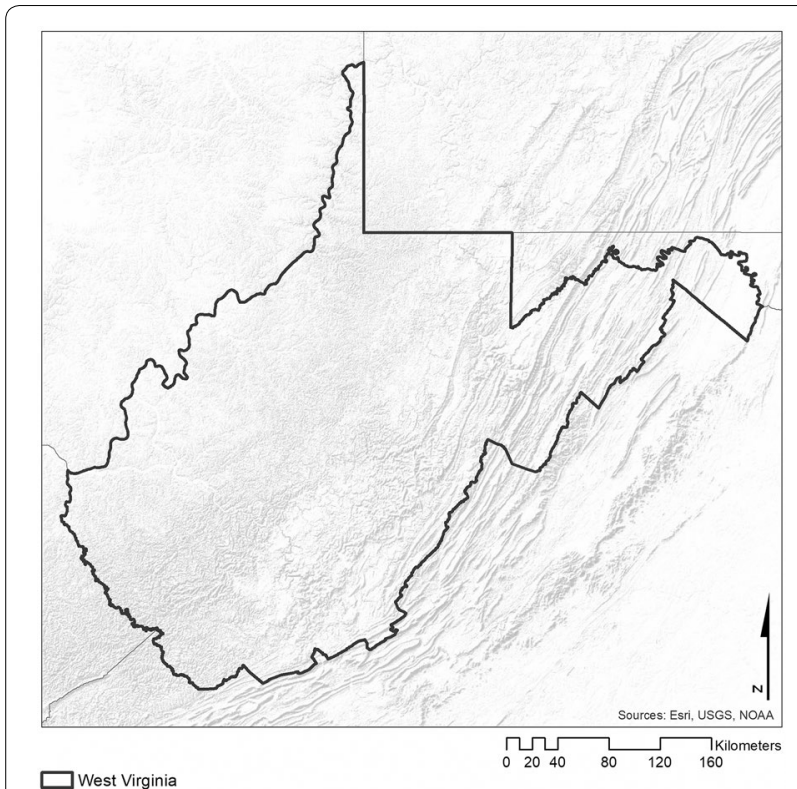

Fig. 5 Raised relief map of West Virginia

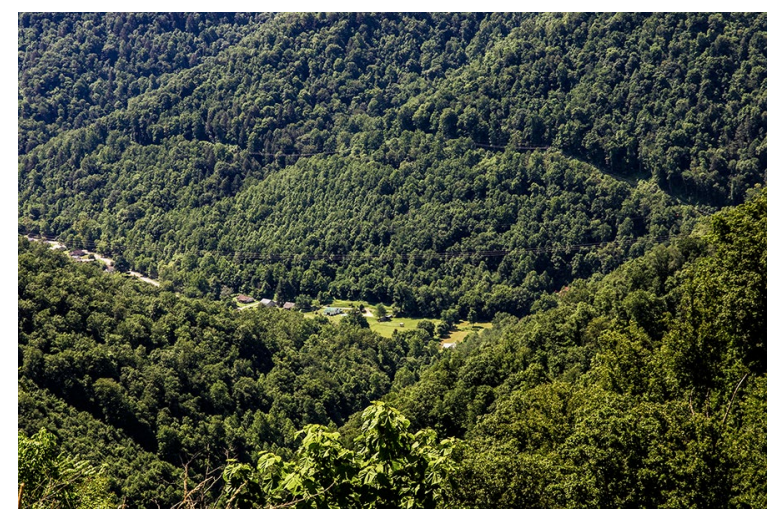

Fig. 6 Typical small settlement on valley floors. Photo: Vincenzo Cribari

the same range of HLC types or 'indicators', or even the same 'grain' of landscape' (Fairclough 2007, p. ix).

WV southern coalfields also present limited historical stratification if compared to the UK, at least with regard to human activities and alterations, although those induced in the landscape in the last two centuries have been dramatic and extensive as noted in previous sections. The prevailing land use has been for the last 50 years, and still is, the extensive surface coal mining. Small settlements are scattered along narrow valley floors-some of them are old coal towns-often following the drainage pattern, while few big towns occupy the major floodplains (Fig. 6). Highways run along the main

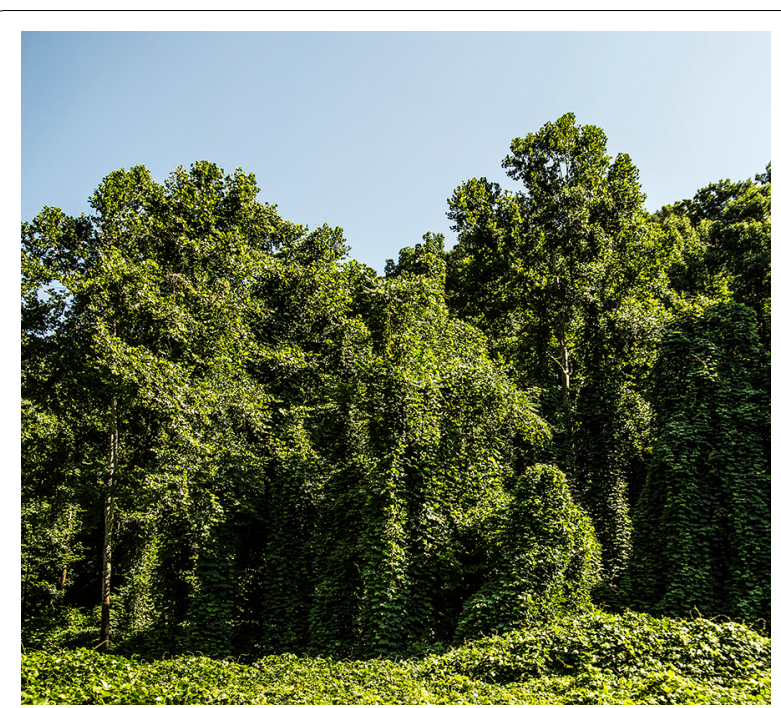

Fig. 7 Kudzu (Pueraria montana) is a weed that covers with a thick layer the existing vegetation killing everything that is underneath. Photo: Vincenzo Cribari

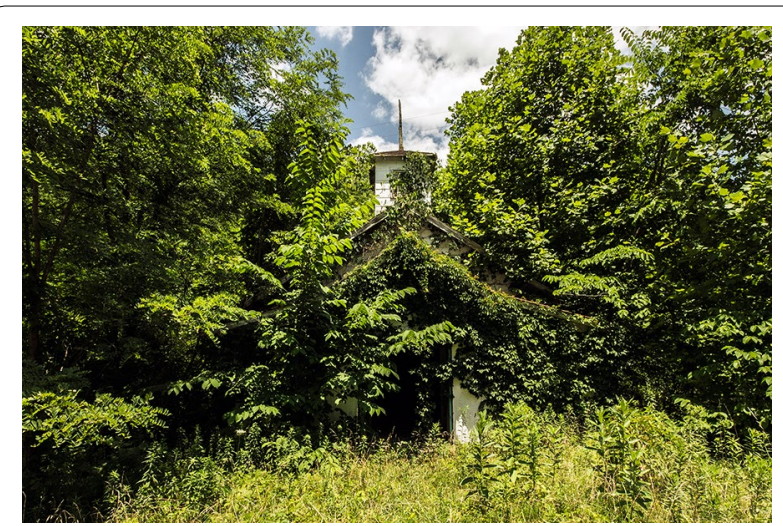

Fig. 8 An example of how vegetation colonizes abandoned buildings. Photo: Vincenzo Cribari

rivers while freight railroads - mainly for coal transportation-also clamber narrower valleys to reach the mining sites usually located at higher elevation.

There are two other noticeable factors that are detrimental for the readability and visibility of landscape features and patterns and that represent significant differences with the English landscape. The first one is the rate at which spontaneous vegetation grows concealing under a verdant thick layer everything that is left unmanaged even for few years. The presence of invasive and rapid growth plants-such as the kudzu that climbs over trees, shrubs, building, etc.- and the mainly wooden constructions increase the risk of obliteration of manmade artefacts (Figs. 7 and 8). As a matter 
of fact, in areas where once there were settlements, the first stages of ecological succession are visible after only a few years since their abandonment. Previous conditions, instead, are only detectable during fieldwork and after a detailed comparison of old maps with the current situation. This factor represents a critical limit when analyzing landscape changes looking, for example, for traces of the past which quickly disappears. The second aspect to consider is the scarce visibility of the areas that undergo the major landscape changes, that is the areas where MTR and surface mining happen. As mentioned in the introduction, they are hard to discern from the main roads and highways and from the most populated places because they are located in the highest elevation spots, on ridges that, due to the topographic configuration, are often concealed by other hills and ridges in the foreground (Fig. 9).

'Many properties of the landscape are scale-dependent, such as diversity, heterogeneity' (Antrop and Eetvelde 2017, p. 90), and landscape classification is very sensitive to scale variability. Therefore, in the context under consideration, a characterization conducted at a broad-regional scale would reflect a coarse-grained landscape, too uniform and unable to register any significant variation. A fine-local scale characterization, on the other hand, would be able to capture local subtleties, but it would be too specific to be generalizable in a character type or area. By way of illustration, if the strong legibility of the UK landscape allows for demarcation of characters types and areas only relying on naked eye interpretations this is not true for the WV southern coalfields. As a matter of fact, also when HLC principle and techniques have been applied in Fort Hood, Texas the methodology adopted has significantly evolved (Fairclough 2007) toward a highly

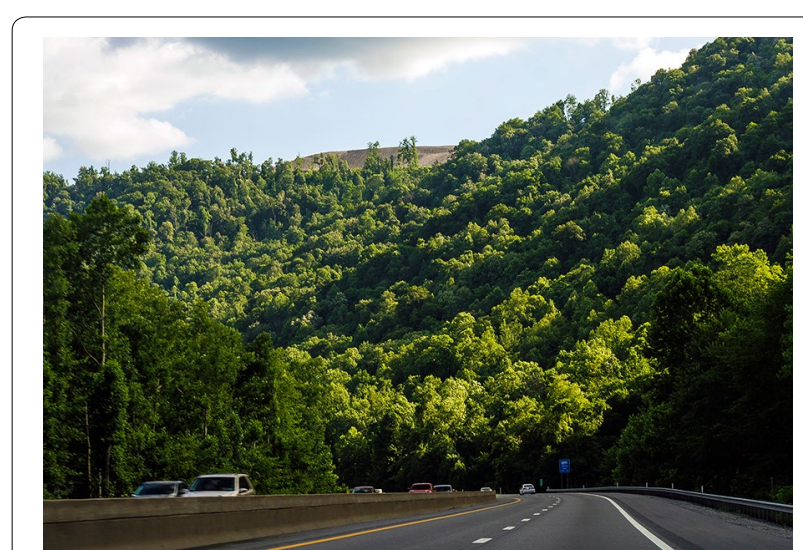

Fig. 9 In the background, view of an MTR site from the Interstate 64 southbound near Charleston, WV. Photo: Vincenzo Cribari automated process which also made up for the quality of the data available for the characterization (Dingwall and Gaffney 2007).

Since, 'scale and context are essential variables to set the conditions for the landscape analysis' (Antrop and Eetvelde 2017, p. 83), the differences in physical attributes between the British and the USA context engender the need to introduce new categories and parameters for assessing the landscape which better reflect the aesthetic, perceptual, and natural aspects of the region. In the absence of an adjusted set of parameters, the risk of undervaluing, underestimating, or overlooking landscape attributes and variations is too high. Therefore, it is essential to finely attuning the method to the scale, grain, and time depth of the landscape under observation.

\section{The second and third dimensions_-historic and cultural background}

While dimensions one and four concern aspects that can be dealt with while developing the actual characterization study by way of practically adapting the method, dimensions two and three are a given that has to do with the historic and cultural background which can only be addressed with acknowledging it.

The second dimension refers to the cultural context which is at the origin of the British character-based approach and to the specific acceptation the word landscape has in that context. In the UK, as well as in Europe, landscape is a cultural construct in which the interaction of natural and human factors-which makes the distinctive character of the landscape-is interpreted and valued through the lenses of the communities that inhabit it. The ELC (Council of Europe 2000) legally broadened this concept declaring that landscape is everywhere-in natural, rural, urban and peri-urban areas-and that can be of outstanding, everyday and even degraded nature. On the contrary, as already extensively discussed, the word landscape in the USA context mostly refers to lands which embed aesthetic and scenic qualities. The emphasis on visual aspects and natural scenery translates to more traditional selective designation-based approaches that operate only on public lands managed by federal agencies.

This leads to the third dimension that refers to the disciplinary context which the British-based methods were set within. It alludes to the contribution of landscape and environmental planners and archeologists to the elaboration of both LCA and HLC methods. In the USA the practical domains in which character assessment-like methods are developed and applied are landscape planning, landscape management, and visual impact assessment all of which operate within public realm. There is a long tradition of visual resource management that started 
in the middle of the 1960s. Guidelines for visual resource and scenery management, scenic quality and aesthetic rating, scenic impacts, visual impact assessments have been developed in the span of more than 40 years by federal agencies such as the U.S. Department of the Interior, Bureau of Land Management, the U.S. Department of Agriculture, Forest Service and Soil Conservation Service, and the U.S. Department of Transportation, Federal Highway Administration. Professionals have been working in the field for assessing the impacts on visual resources of highways, renewable energy facilities, and, more broadly, infrastructural projects. All of these knowhow and expertise should be taken advantage of incorporating them into the landscape characterization process amplifying the relevance of the perceptual aspects and landscape aesthetics-which importance in the American psyche can be traced back to early nature writings by Ralph Waldo Emerson, Henry David Thoreau and others, as well as to the landscape paintings of Thomas Cole and Frederick Church.' (Palmer and Smardon 2018, p. 131) and expanding their range of application.

\section{The fourth dimension-political and institutional environment}

The fourth dimension refers to the political and institutional environment within which the character-based method is implemented. As Bell claims 'Europe in general is in a strong position in terms of having (...) a legal framework within which to ensure that [landscape] is taken into account in a proper way at both strategic and project scales.' (2017, p. 87) In the USA, instead, a legal framework-such as the ELC for the European Union (EU) countries - that advocates the right to landscape and enforces its management and/or protection as a whole is absent. Referring to LCA, Fairclough et al. state that the approach 'is weak in those countries with undeveloped planning systems' (Fairclough et al. 2018b, p. 280 ). This is the case of the USA where a national landuse planning is absent and local governments exercise the greatest control over the use and development of the land through local zoning ordinances and local planning (Kayden 2000).

Whereas in the EU the idea of an inclusive landscape, comprising both everyday and outstanding landscapes, 'is a taken-for-granted concept' (Fairclough et al. 2018b, p. 8 ), in the USA the approach remains more selective and is based on the appreciation of natural scenery, historic objects, and wilderness ideals. In this legal context, due to the absence of the enforcement of overall landscape management and protection, the idea of inventorying and assessing the landscape could appear as a purposeless rhetorical exercise if practiced outside of specific legal boundaries. Though, under current law, within WV southern coalfields, a landscape characterization for the purpose of designating areas unsuitable for surface coal mining sounds reasonable and meaningful. In fact, the Surface Mining Control and Reclamation Act of 1977 determined that each State should 'establish a planning process enabling objective decisions based upon competent and scientifically sound data and information as to which, if any, land areas of a State are unsuitable for all or certain types of surface coal mining operations' (U.S. Section 522(a)(1)). Upon petition, States should declare areas unsuitable if surface mining 'affect fragile or historic lands in which such operations could result in significant damage to important historic, cultural, scientific, and esthetic [sic] values and natural systems' (U.S. Section 522(a)(3)(B)).

The state of WV in its code (West Virginia State Code 1977), in addition to the areas declared unsuitable upon petition, establishes that, with few exceptions, lands unsuitable for surface mining also are:

(1) Within the boundaries of units of the national park system, the national wildlife refuge systems, the national system of trails, the national wilderness preservation system, the wild and scenic rivers system $(\ldots)$

(2) [Areas w]hich will adversely affect any publicly owned park or places included in the national register of historic sites, or national register of natural landmarks (...)

(3) Within one hundred feet of the outside right-ofway line on any public road (...)

(4) Within three hundred feet from any occupied dwelling (West Virginia State Code 1977, \$22-322(d)).

This part of the code clearly shows the political and institutional awareness of the disruptive nature of surface mining and the necessity to keep it out of sight and out of range of valued and inhabited areas for safety and lands protection.

For the petition process, the WV code establishes that '[a]ny person having an interest which is or may be adversely affected has the right to petition the director [of the Division of Mining and Reclamation (DMR)] to have an area designated as unsuitable for surface-mining operations (...) The petition shall contain allegations of fact with supporting evidence which would tend to establish the allegations.' (West Virginia State Code 1977, \$223-22(b)) After receiving the petition the DMR develops a study of the area, and, after holding a public hearing in the locality potentially adversely affected by surface mining, a decision is made regarding the petition and the reasons therefor. 
As plainly stated in the code, the process of declaring an area unsuitable for surface mining needs 'supporting evidence.' This means that a landscape characterization, a 'competent and scientifically sound' data, can be very valuable both when petitioning and when making the decision regarding the petition. By way of landscape characterization, it is possible to determine with scientifically sound method the 'fragile or historic lands in which [surface mining] operations could result in significant damage.' Moreover, since the landscape characterization incorporates, as already noted, public consultation and participation, it will represent both, a scientifically and democratically sound process. This leads to define a fifth dimension of transferability, the social one. Fairclough et al. (2018b) don't include this dimension in their considerations, however the authors deem it relevant for the context of their reflections.

\section{A fifth dimension-the social context}

LCA, despite being mainly based on professional judgment, is increasingly including various degrees of public involvement along the process in order to achieve a higher level of landscape democratization. However, in the European context, effective public participation still represents a challenge for policymakers and administrators despite its legal enforcement for example through the ELC (Jones 2007; Jones and Stenseke 2011a, b). Though the absence of a legal framework that establishes formal processes and procedures for public participation makes the effort of community involvement even more difficult. According to Jones and Stenseke, among other challenges, "[e]ffective public participation faces the challenges of $(\ldots)$ creating the trust necessary for a successful process, combating apathy or passive and even active opposition, and overcoming powerful vested interests. (2011aa, b, p. 20) As it can be inferred from the description of the region provided in the previous paragraphs, some of the 'roadblocks to achieving genuine levels of participation' can be identified in WV southern coalfields on both the "power-holders" and the "have-nots" sides. They include 'paternalism, and resistance to power redistribution' on the power-holders' side and 'inadequacies of the poor community's political socioeconomic infrastructure and knowledgebase, plus difficulties of organizing a representative and accountable citizens' group in the face of futility, alienation, and distrust' on the havenots' side (Arnstein 1969, p. 217). Although Arnstein identifies typologies of citizen participation using examples from three federal social programs implemented in the fifties and sixties in the urban context-urban renewal, antipoverty, and Model Cities-it is possible to recognize several analogies with the context under consideration. The Appalachian region represents what has been identified as an internal colony (Lewis et al. 1978), a 'peripheral region within an advanced capitalist society' (Walls 1978, p. 339), an area succumbing to cultural hegemony and capitalist domination. These models portray a pattern of outside manipulation and exploitation and describe a region 'of company-dependent residents who have been unable to transition successfully from those industry's boom eras [the author refers to raw materials extraction industries] or escape the lingering effects of industry environmental, health and economic degradation.' (Robinson 2015, p. 75)

In WV southern coalfields, after years of organized resistance against natural resources extraction and not enough battles won, the communities feel vulnerable and deceived. After years of deception, communities are distrustful and not inclined to be part of processes-like for example the LCA-they perceive as imposed upon them top-down. Under these circumstances, it is difficult to involve community members in participatory activities and to gain local knowledge. Nevertheless, there are innovative methods for gaining local knowledge in an indirect fashion that can be introduced in an LCA process-e.g. the use of online digital environments as 'found in the field' data sources and platforms for virtual participation. Social media, for example, can be 'vehicles for knowledge acquisition' (van Lammeren et al. 2017, p. 136), web-based methods can be used in landscape and urban planning and design (de Waal et al. 2013; Eräranta et al. 2015), participatory GIS can be used for mapping resource distribution and land use (Wartmann and Purves 2017), and so on and so forth. All of them represent innovative engaging methods allowing different levels of interactions that can be used as alternatives to traditional participatory methods when the communities that should be involved in the characterization process, show forms of resistance and distrust.

\section{Conclusions}

Although acknowledged as a necessary and worthwhile endeavour for the sake of landscape identification, management, conservation, and preservation, the LCA method is not immediately translatable and transferrable. It needs to be adapted in order for it to be able to address the specificities of a context that is not just physically and geographically very different from the one the method was designed for, but whose legal, historical, cultural, and social underpinnings substantially differ as well.

As noted in these pages, the five dimensions of the transferability of the method to the USA context can be addressed mainly in the practice for example adding to the toolbox of the landscape analyst non-traditional techniques-such as highly automated processes of landscape features identification-and the expertise and know-how 
that come with the long tradition of visual resources management.

The authors deem it important to contribute to the discussion regarding the application of LCA outside the UK with the aim of offering a new perspective to the debate and to enable a deeper understanding of the challenges of implementing the method. It is the authors' prospect that this article might stimulate further theoretical developments and practical attempts that would set new research agendas for the North American landscape.

\section{Abbreviations}

AP: Appalachian Plateau; DMR: Division of Mining and Reclamation; ELC: European Landscape Convention; EU: European Union; HLC: Historic Landscape Characterisation; LCA: Landscape character assessment; MTR: Mountaintop removal; NASA: National Aeronautics and Space Administration; TEUI:Terrestrial Ecological Unit Inventory; UK: United Kingdom; U.S.: United States; USA: United States of America; WV: West Virginia.
\end{abstract}

\section{Acknowledgements}

This work is supported by the USDA National Institute of Food and Agriculture, Hatch project \#1015398

\section{Authors' contributions}

This article is the result of a joint effort. All authors read and approved the final manuscript.

\section{Funding}

Not applicable.

\section{Availability of data and materials}

Not applicable.

\section{Competing interests}

The authors declare no competing interests.

\begin{abstract}
Author details
${ }^{1}$ School of Design and Community Development, Davis College of Agriculture, Natural Resources and Design, West Virginia University, 4316 Agricultura Sciences Building, 1194 Evansdale Drive, Morgantown, WV 26506-6108, USA. ${ }^{2}$ School of Design and Community Development, Davis College of Agriculture, Natural Resources and Design, West Virginia University, 4314 Agricultura Sciences Building, 1194 Evansdale Drive, Morgantown, WV 26506-6108, USA. ${ }^{3}$ School of Design and Community Development, Davis College of Agriculture, Natural Resources and Design, West Virginia University, 4313 Agricultural Sciences Building, 1194 Evansdale Drive, Morgantown, WV 26506-6108, USA.
\end{abstract}

Received: 6 January 2020 Accepted: 25 May 2020

Published online: 01 June 2020

\section{References}

Albrecht G (2005) 'Solastalgia': a new concept in health and identity. PAN Philos Activism Nat 3:44-59

Antrop M, Eetvelde V (eds) (2017) Landscape perspectives: the holistic nature of landscape. Springer, Dordrecht

Arnstein S (1969) A ladder of citizen participation. J Am Instit Plan 35(4):216-224

Bartlett D, Gomez-Martin E, Milliken S, Parmer D (2017) Introducing landscape character assessment and the ecosystem service approach to India: a case study. Landsc Urban Plan 167:257-266

Bell S (2017) Adjusting to renewable energy in a crowded Europe. In: Aposto D, Palmer J, Pasqualetti M, Smardon R, Sullivan R (eds) The renewable energy landscape. Routledge, London

Brabyn L (2009) Classifying landscape character. Landsc Res 34(3):299-321
Braun E (1950) Deciduous forests of eastern North America. Hafner Press/ Macmillan, New York

Butler A (2016) Dynamics of integrating landscape values in landscape character assessment: the hidden dominance of the objective outsider. Landsc Res 41(2):239-252

Core E (1966) Vegetation of West Virginia. Parsons, McClain

Council of Europe (2000) European landscape convention (Council of Europe Treaty Series-No. 176). https://www.coe.int/en/web/conventions/fulllist/-/conventions/treaty/176. Accessed 18 Dec 2019

Council of Europe (2005) Council of Europe framework convention on the value of cultural heritage for society (Council of Europe Treaty SeriesNo. 199). https://www.coe.int/en/web/conventions/full-list/-/convention s/treaty/199. Accessed 18 Dec 2019

Crutzen P (2002) Geology of mankind: the anthropocene. Nature 415:23

de Waal R, Kempenaar A, van Lammeren R, Stremke S (2013) Application of social media in a regional design competition: a case study in the Netherlands. Proc Digit Landsc Archit 2013:186-199

Dingwall L, Gaffney V (2007) Heritage management at Fort Hood, Texas: experiments in historic landscape characterization. Archaeopress, Oxford

Eggleston J (1975) A bicentennial story: history of West Virginia's mineral industries. Newsletter of West Virginia Geological and Economic Survey, Morgantown, pp 23-33

Egoz S, Makhzoumi J, Pungetti G (2011) The right to landscape: contesting landscape and human rights. Routledge, Abingdon

Eller R (1982) Miners, millhands, and mountaineers. Industrialization of the Appalachian South, 1880-1930. The University of Tennessee Press, Knoxville

Eräranta S, Kahili-Tani M, Nummi-Sund P (2015) Web-based public participation in urban planning competitions. Int J E-Plan Res 4(1):1-18

Fairclough G (2007) Preface: new ways in the new world. In: Dingwall L, Gaffney V (eds) Heritage management at Fort Hood, Texas: experiments in historic landscape characterization. Archaeopress, Oxford

Fairclough G, Herring P (2016) Lens, mirror, window: interactions between historic landscape characterisation and landscape character assessment. Landsc Res 41(2):186-198

Fairclough G, Sarlöv Herlin I, Swanwick C (eds) (2018a) Routledge handbook of landscape character assessment. Routledge, Abingdon

Fairclough G, Sarlöv Herlin I, Swanwick C (2018b) Landscape character approaches: introduction. In: Fairclough G, Sarlöv Herlin I, Swanwick C (eds) Routledge handbook of landscape character assessment. Routledge, Abingdon

Fenneman N (1928) Physiographic divisions of the United States. Ann Assoc Am Geogr 18(4):261-353

Garvin J (1907) West Virginia agricultural resources and possibilities. West Virginia State Board of Agriculture. The Tribune Printing Co, Charleston

Hendryx M (2018) Moving beyond case studies: research examples from mountaintop removal coal mining. In: White W, Herman J, Herman E, Rutigliano M (eds) Karst groundwater contamination and public health Advances in Karst Science. Springer, Cham

Hinkle C, McComb W, Safley J, Schmalzer P (1993) Mixed mesophytic forests. In: Martin W, Boyce S, Echternacth A (eds) Biodiversity of the Southeastern United States. Upland Terrestrial Communities. Wiley, New York

Hooke R (1999) Spatial distribution of human geomorphic activity in the United States: comparison with rivers. Earth Surf Proc Land 24(8):687-692. https://doi.org/10.1002/(SICI)1096-9837(199908)24:83.0.CO;2-\%23

Hufford M (n.d.) Landscape and history at the headwaters of the Big Coal River Valley: an overview. Library of Congress, Washington

Jones M (2007) The European landscape convention and the question of public participation. Landsc Res 32(5):613-633

Jones M, Stenseke M (eds) (2011a) The European landscape convention: challenges of participation. Springer, Dordrecht

Jones M, Stenseke M (2011 b) The issue of public participation in the European landscape convention. In: Jones M, Stenseke M (eds) The European landscape convention: challenges of participation. Springer, Dordrecht

Kayden J (2000) National land-use planning in America: something whose time has never come. Washington Univ J Law Policy 3(445):445-471

Landscape Institute, Institute of Environmental Management \& Assessment (2013) Guidelines for landscape and visual impact assessment. Routledge, London 
Lewis R (1998) Transforming the Appalachian Countryside: Railroads, Deforestation, and Social Change in West Virginia, 1880-1920. University of North Carolina Press, Chapel Hill

Lewis P and Associates (1969) Upper Mississippi river comprehensive basin study. Appendix B aesthetic and cultural values. U.S. Department of Interior, National Park Service, Northeast Region, Kaukana

Lewis H, Johnson L, Askins D (eds) (1978) Colonialism in modern America: The Appalachian case. Appalachian Consortium Press, Boone

Li G, Zhang B (2017) Identification of landscape character types for transregional integration in the Wuling Mountain multi-ethnic area of southwest China. Landsc Urban Plan 162:25-35

McGinley P (2004) From pick and shovel to mountaintop removal: environmental injustice in the Appalachian coalfields. Environ Law 34(1):21-106

NASA Earth Observatory (n.d.) World of change: mountaintop mining, West Virginia. https://earthobservatory.nasa.gov/world-of-change/Hobet. Accessed 26 Nov 2019

Ode A, Tveit M, Fry G (2008) Capturing landscape visual character using indicators: touching base with landscape aesthetic theory. Landsc Res 33(1):89-117

Olwig K (2016) Virtual enclosure, ecosystem services, landscape's character and the 'rewilding' of the commons: the 'lake district' case. Landsc Res 41(2):253-264

Palmer J, Smardon R (2018) US approaches related to landscape character assessment. In: Fairclough G, Sarlöv Herlin I, Swanwick C (eds) Routledge handbook of landscape character assessment. Routledge, Abingdon

Palmer M, Bernhardt E, Schlesinger W, Eshleman K, Foufoula-Georgiou E, Hendryx M, Lemly A, Likens G, Loucks O, Power M, White P, Wilcock P (2010) Mountaintop mining consequences. Science 17(5962):148-149

Pillsbury R (ed) (2006) The new encyclopedia of southern culture. Volume 2: Geography. University of North Carolina Press, Chapel Hill

Research Planning and Design Associates Inc (1970) North Atlantic regional water resources study. Appendix N visual and cultural environment. North Atlantic Regional Water Resources Study Coordinating Committee, Amherst

Robinson C (2015) An exploration of poverty in Central Appalachia: questions of culture, industry, and technology. KOME 3(2):75-89

Ross M, McGlynn B, Bernhardt E (2016) Deep impact: effects of mountaintop mining on surface topography, bedrock structure, and downstream waters. Environ Sci Technol 50(4):2064-2074. https://doi.org/10.1021/acs. est.5b04532

Sarlöv Herlin I (2016) Exploring the national contexts and cultural ideas that preceded the Landscape Character Assessment method in England. Landsc Res 41(2):175-185

Stahlschmidt P, Swaffield S, Primdahl J, Nellemann V (2017) Landscape analysis. Investigating the potentials of space and place. Routledge, Abingdon

Staniscia S, Yuill C (2017) Reflections on mountaintop mining as industrial heritage. Change Over Time 7(1):30-51. https://doi.org/10.1353/ cot.2017.0002

Stretesky P, Lynch M (2011) Coal strip mining, mountaintop removal, and the distribution of environmental violations across the United States, 2002-2008. Landsc Res 36(2):209-230
Swanwick C, Land Use Consultants (2002) Landscape character assessment. Guidance for England and Scotland. In: Scottish Natural Heritage. https ://www.nature.scot/sites/default/files/2018-02/Publication\%202002\%20 -\%20Landscape\%20Character\%20Assessment\%20guidance\%20for \%20England\%20and\%20Scotland.pdf. Accessed 23 Apr 2019

Swanwick C, Fairclough G (2018) Landscape character. Experience from Britain. In: Fairclough G, Sarlöv Herlin I, Swanwick C (eds) Routledge handbook of landscape character assessment. Routledge, Abingdon

Thornbury W (1965) Regional geomorphology of the United States. Wiley, New York

Tudor C (2014) An approach to landscape character assessment (Report No. NE579). In: Natural England. https://assets.publishing.service.gov.uk/ government/uploads/system/uploads/attachment_data/file/691184/ landscape-character-assessment.pdf. Accessed 23 Apr 2019

U.S. (1965) Federal Water Resources Planning Act

U.S. (1977) Surface Mining Control and Reclamation Act

U.S. Department of Agriculture, Forest Service (2005) Terrestrial Ecological Unit Inventory Technical Guide

U.S. Energy Information Administration (2019) U.S. coal reserves with data for 2018. https://www.eia.gov/coal/reserves/. Accessed 24 Oct 2019

van Lammeren R, Theile S, Stemmer B, Bruns D (2017) Social media. In: van den Brink A, Bruns D, Tobi H, Bell S (eds) Research in landscape architecture. Routledge, London

Walls D (1978) Internal colony or internal periphery? A critique of current models and an alternative formulation. In: Lewis $H$, Johnson L, Askins D (eds) Colonialism in modern America: the Appalachian case. Appalachian Consortium Press, Boone

Warnock S, Griffiths G (2015) Landscape characterisation: the living landscapes approach in the UK. Landsc Res 40(3):261-278

Wartmann F, Purves R (2017) What's (not) on the map: landscape features from participatory sketch mapping differ from local categories used in language. Land 6(4):79-79. https://doi.org/10.3390/land6040079

West Virginia State Code (1977) Surface Coal Mining and Reclamation Act

West Virginia University (2018) Appalachian Geopark. https://appalachiangeop ark.wvu.edu/home. Accessed 12 Nov 2019

Wickham J, Bohall Wood P, Nicholson M, Jenkins W, Druckenbrod D, Suter G, Strager M, Mazzarella C, Galloway W, Amos J (2013) The overlooked terrestrial impacts of mountaintop mining. Bioscience 63(5):335-348. https ://doi.org/10.1525/bio.2013.63.5.7

Woods B, Gordon J (2011) Mountaintop removal and job creation: exploring the relationship using spatial regression. Ann Assoc Am Geogr 101(4):806-815

\section{Publisher's Note}

Springer Nature remains neutral with regard to jurisdictional claims in published maps and institutional affiliations.

\section{Submit your manuscript to a SpringerOpen ${ }^{\circ}$ journal and benefit from:}

- Convenient online submission

- Rigorous peer review

- Open access: articles freely available online

- High visibility within the field

- Retaining the copyright to your article

Submit your next manuscript at springeropen.com 